\title{
A DEAF AND A HEARING STUDENT LEARNING PORTUGUESE AND LIBRAS IN A TANDEM CONTEXT
}

\author{
Uma aluna surda e uma ouvinte aprendendo Português e \\ Libras em um contexto de tandem
}

\author{
Francisco José Quaresma de FIGUEIREDO' \\ Quintino Martins de OLIVEIRA²
}

\begin{abstract}
Inclusive education in Brazil has created a linguistic reality at schools in which deaf and hearing people share the same space (QUADROS; KARNOPP, 2004). However, some obstacles make it hard for this interaction to flow naturally, both by deaf people who do not master Portuguese and hearing people who do not know Brazilian Sign Language. Various studies about the process of teaching and learning spoken languages emphasize the relevance of collaborative interaction in pairs or in groups in the co-construction of knowledge (FIGUEIREDO, 2006; SWAIN, 1995). It is in this collaborative context that the present research takes place with the objective of promoting authentic contact between deaf and hearing people, who are beginners in the languages being studied, by means of tandem language learning. It is an approach used in the learning of spoken languages with the purpose of promoting linguistic and cultural exchange among people whose native languages are different (BRAMMERTS, 1996). We intended to verify the possible benefits of such approach to the speakers of languages of different modalities: a spoken language (Portuguese) and a visual-spatial language (Brazilian Sign Language - Libras). A deaf student and a hearing one who take Brazilian Sign Language as a major at the Universidade Federal de Tocantins, Porto Nacional, Brazil, took part in this study. They had to teach each other idiomatic expressions in their own languages. The collaborative strategies used by them and the negotiation established in such encounters show that the interaction among deaf and hearing students contribute to the process of learning the languages.
\end{abstract}

Keywords | Brazilian Sign Language. Tandem learning. Interaction. Collaboration.
Resumo | A educação inclusiva no Brasil formatou um cenário linguístico nas escolas em que surdos e ouvintes passam a compartilhar o mesmo espaço (QUADROS; KARNOPP, 2004). No entanto, alguns percalços dificultam o fluir natural dessa interação, tanto pelos surdos que não dominam a língua portuguesa, quanto pelos ouvintes que não sabem libras. Diversos estudos no contexto de ensino e aprendizagem de línguas orais salientam a relevância da interação colaborativa entre pares ou em grupos na construção do conhecimento (FIGUEIREDO, 2006; SWAIN, 1995). É nesse contexto colaborativo que esta pesquisa surge com o intuito de promover contato autêntico entre surdos e ouvintes, iniciantes nas línguas em estudo, por meio da aprendizagem em tandem. Trata-se de uma abordagem utilizada na aprendizagem de línguas orais, cujo propósito é a promoção do intercâmbio linguístico e cultural entre pessoas que possuem línguas diferentes (BRAMMERTS, 1996). Pretendemos verificar os possíveis benefícios dessa abordagem para falantes de línguas de modalidades diferentes: oral auditivo (português) e visuoespacial (Libras). Participaram do estudo uma aluna surda e uma ouvinte do curso de Letras: Libras da Universidade Federal do Tocantins, Porto Nacional, Brasil, em que tinham de ensinar, uma para a outra, expressões idiomáticas em suas línguas. As estratégias colaborativas adotadas por elas e as negociações estabelecidas nos momentos desses encontros apontam que a interação entre os alunos surdos e ouvintes contribuem para o processo de aprendizagem das línguas em questão.

Palavras-chave | Libras. Aprendizagem em tandem. Interação. Colaboração.

$\overline{1 \text { Figueiredo. UFG. E-mail: fquaresma@terra.com.br. ORCID ID: https://orcid.org/0000-0002-5936- }}$ 2 Oliveira. UFT. E-mail: qmoliveira.neto@gmail.com. ORCID ID: https://orcid.org/0000-0001-54410062 
- Learning libras and portuguese in a tandem context: a study conducted with one deaf and one hearing student

\section{Introduction}

Brazil's current inclusive educational philosophy has led to a significant increase in the number of deaf people in the educational sphere. In consequence, communication at schools starts to contemplate another language whose modality ${ }^{3}$ is completely different from that of the Portuguese language, defined as a visual-spatial modality, as is the case of Brazilian Sign Language (Libras) (OLIVEIRA, 2007; OLIVEIRA-SILVA, 2005; QUADROS; KARNOPP, 2004).

Many studies have been conducted on the learning of Portuguese as a second language, in the written modality, by deaf people. Such studies seek to verify if the methodologies developed in the teaching of spoken languages can be applied when one of the languages is of the visual-spatial modality.

In the context of spoken languages, the work in pairs and in groups has proven to be effective in learning different contents, bringing new possibilities for teaching methodologies to the language learning context (DONATO; MCCORMICK, 1994; FIGUEIREDO, 1999, 2001, 2005, 2006; LANTOLF; APPEL, 1994; SWAIN, 1995). Hence, this collaborative approach in education is gaining space in research in the area of applied linguistics.

Collaborative learning refers to "educational situations in which two or more people learn ortry tolearn something together, be it through interactions in the classroom or outside of it" (FIGUEIREDO, 2006, p. 12). This approach goes by the premise that interaction is a fundamental factor in the cognitive and linguistic development of the learner, which can also occur by means of a collaborative process known as tandem learning. This is a process of linguistic and cultural exchanges between individuals who speak different languages, with purposes of learning the target language ${ }^{4}$ in a collaborative way (BENEDETTI, 2010; GARCIA, 2013; TELLES, 2009). Thus, we intend to verify if such benefits can be perceived in the interaction between deaf and hearing students, because little is known about how these interactions are established when the linguistic pair is constituted by languages of different modalities, as it is in the case of Libras and Portuguese.

3 Modality is understood as the way in which languages are perceived and produced, and it can be spoken or signed (OLIVEIRA-SILVA, 2017).

4 Target language (T-language) is the foreign language the subject is learning, different from L1 (FIGUEIREDO, 2006). 


\section{Mediating strategies in tandem learning}

According to Vassallo and Telles (2009), tandem learning offers opportunities for interactions in which one person teaches their language to another person, and vice-versa, freely, without following a fixed curricular program. The goal of this proposition is for the peers to develop communicative capabilities in the foreign language (BRAMMERTS, 2002). Tandem can be done face-to-face or at a distance, using technological resources (FIGUEIREDO; SILVA, 2016). According to Benedetti (2010, p. 21), the tandem learning modality is known "as a complimentary proposal to the formal learning of the foreign language".

This proposal of teaching and learning languages arises in the context in which the contact between two native speakers ${ }^{5}$ of different foreign languages is made possible. The practice of learning foreign languages via the tandem context is characterized, according to Benedetti (2010, p. 22), first

\footnotetext{
[...] with the accord, between the members of the pair, of the place previously agreed on for one to learn the language of the other through a conversation in the target language and mutual help. The time was divided in two balanced parts, with one period for each language. After that, the languages were swapped, and the roles inverted, so that the one who was previously teaching their language to the partner, the following moment helped them learn their mother tongue.
}

The interaction between the learners, in a tandem session, must obey some principles, such as: symmetrical sociability (there is an alternation of roles: in one session one of the participants acts as a teacher of their native language; in the other session, they act as a learner of the target language); reciprocity (each learner must help their partner in learning the language, receiving as much help as they offer); autonomy (both learners take personal responsibility for their respective part of the tandem sessions and determine their own learning objectives and methods); interculturality (both learners have access to different languages and different cultures); and bilingualism (the two languages of the partnership must be used in a balanced way by the learners (BRAMMERTS, 2002; SOUZA, 2003, 2006; VASSALO; TELLES, 2009).

5 In a tandem perspective, the subjects must be native speakers of the languages involved. However, further studies of tandem learning at a distance, such as teletandem, widen the profile of the participants, considering also the proficient speakers of the target language (T-language) (BENEDETTI, 2010). 
- Learning libras and portuguese in a tandem context: a study conducted with one deaf and one hearing student

In tandem sessions, learners can use different mediating strategies to assist them in the learning of languages. Figueiredo (2005, p. 124) presents some mediating strategies, which are defined by Villamil and Guerrero (1996) as "the activities that facilitate the fulfilment of the objectives of a task". They consist of, for example, the use of symbols, appointments, mimicry, images, dictionaries, grammars, objects, as well as the use of the mother tongue as a means of facilitating the execution of the task.

Learners can also offer one another guidance that can occur by means of questions or instructions, known as scaffolding. Scaffolding is described as a process that allows the child, or the learner, to solve a problem, finish a task or achieve a goal that would be beyond their efforts, in case they did not have help from another person (WOOD; BRUNER; ROSS, 1976). Scaffolding must only be offered when the learner requires help, being taken away in the moment they manage to develop the activity alone (LANTOLF; APPEL, 1994). Thus, collaborative learning is a process in which there is the use of different mediating strategies that promote the co-construction of knowledge in a linguistic and sociocultural context (FIGUEIREDO, 2006).

\section{The study}

Two undergraduate students who take Libras as a major at the Universidade Federal de Tocantins, Porto Nacional, Brazil, took part in this case study. They had been taking the course for two and a half years. Both are adults, and their identities were preserved by using pseudonyms, chosen by them: Cecília, 23, hearing, and Luíza, 24, deaf.

Two face-to-face tandem sessions were conducted, and each occurred in different days, and lasted for one hour. In the first meeting, Luiza taught Libras to Cecília. In the second one, Cecília taught written Portuguese to Luíza. They chose 'idiomatic expressions' as the theme to be worked on.

Idiomatic expressions are combinations of words, used in a specific sequence and consecrated by the use, whose meaning is given metaphorically through the totality of the expression, which is socially accorded, and not given by the meaning of the isolated words that compose such expression (BIDERMAN, 2001).

Idiomatic expressions may or may not have a correspondent in the other language. Thus, not all idiomatic expressions in Portuguese have correspondents in Libras, and vice-versa. There are also idiomatic expressions that are specific to certain languages. For 
example, the expression "olho caro"6 (literally, 'expensive eye') that exists in Libras does not have a correspondent in Portuguese (FARIA, 2003).

Idiomatic expressions and metaphors are constructed from the social, cultural, and linguistic context of their speakers. According to Oliveira (2010, p. 2836-2837),

[it is] incontestable that deaf and hearing people have different physical and cultural experiences. For the deaf, the sense of vision is more influent in the process of signification of the world and the acquisition of knowledge than the sense of hearing, since these comprehend the world predominantly through visual experiences (so much so that they use a visual-spatial language).

Before the tandem sessions, a meeting was set up in which the procedures of this study were made clear, and the consent forms for the use of the data generated in the research were also collected. After each tandem session, an individual interview with each participant was done in order to clarify their perceptions about their role in this interactive process of language learning. Each interview lasted for about 20 minutes and was recorded in audio and video.

The use of the video as a tool in the data collection procedure was needed due to the fact that one of the languages involved in the study is visual-spatial. It was agreed and made clear that all collected data would be transcribed and translated into Portuguese, thus guaranteeing the preservation of their identities and images.

This research is a qualitative case study analysis of the experiences of a hearing student and a deaf student who took part in face-to-face tandem sessions. Case study methodology allows for the use of several data collection instruments to provide a better view of the event or of the phenomenon being investigated (BOGDAN; BIKLEN, 1994; NUNAN, 1992; SELIGER; SHOHAMY, 1989).

All material used in the tandem learning sessions was produced by the participants, who were alone in the classroom during the sessions. They used images taken from the Internet that were shown to their partners in their laptops, and they also used the whiteboard and markers. All the sessions were video-recorded for further analysis, and the interactions in Libras were later translated into Portuguese. Cecília prepared a PowerPoint file with fourteen illustrative images with examples of idiomatic expressions in Portuguese,

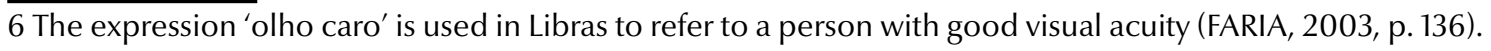


- Learning libras and portuguese in a tandem context: a study conducted with one deaf and one hearing student

with their meaning written below, also in Portuguese. Besides, she also produced two written tasks. In the first one, there were images that illustrated literally some idiomatic expressions in Portuguese, such as, for instance, the image of a person swallowing a frog. This way, her deaf partner, when seeing the image, was expected to write the expression 'engolir um sapo' ${ }^{\prime}$ in Portuguese. In the other task, the deaf partner had to match the images to their respective meanings written in Portuguese.

Luíza, the deaf participant, prepared a PowerPoint presentation containing six images that reflected some idiomatic expressions specific to Libras. This task was only signed, and she did not use any printed material. She explained the meaning of the idiomatic expressions to Cecília, her hearing partner. After that, Luíza asked Cecília to make sentences using the idiomatic expressions.

\section{Analysis of the mediating strategies in the tandem sessions, and the perceptions of the participants about such collaborative learning process}

In this study, the resources used by the participants, such as the whiteboard, markers of different colors, Microsoft PowerPoint showing slides with images, gestures, written explanations and drawings proved to be rather positive. They proved to be useful resources because they helped the learners to interact during the sessions and to do the tasks. They also helped the participants to provide each other with adequate input in the languages to be learned.

In excerpt 1, Cecília is teaching her deaf partner the idiomatic expression 'ao pé da letra's in Portuguese. She walks up to the whiteboard and writes in blue: "Ele leva tudo ao pé da letra" ${ }^{\prime \prime}$, and then draws a human foot and the letter ' $\mathrm{L}^{\prime}$ with two feet, as can be seen in the following figure.

\footnotetext{
7 Literally, the expression means 'to swallow a frog'. In general terms, however, the meaning is closer to 'swallow one's pride'.

8 When translated literally into English, 'ao pé da letra' becomes 'to the foot of the letter'; otherwise, it can be translated as the word 'literally'.

9 Literally: "He takes everything to the foot of the letter".
} 


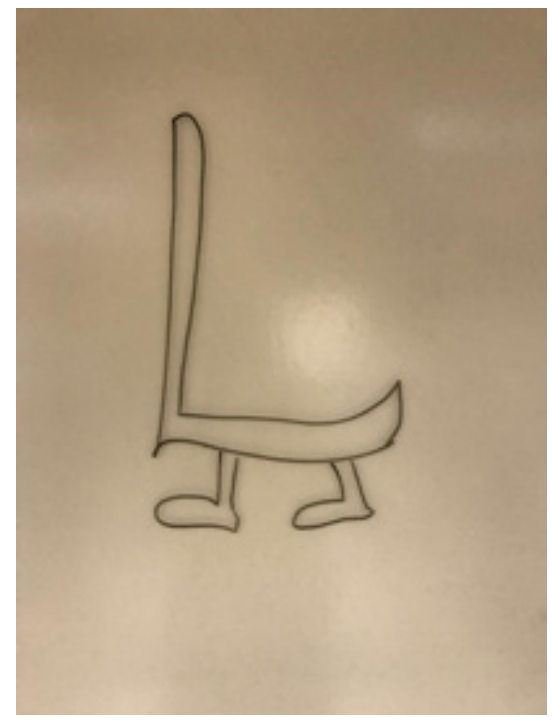

Figure 1. "Ao pé da letra".

Source: Material used during the Portuguese class

When showing the drawing of the foot, Luíza identifies the meaning of the word 'foot' and, after that, she produces the sign for 'human foot' in Libras. From that understanding, Cecília explains that it does not make sense to translate idiomatic expressions literally and evokes the concept of idiomatic expressions as closed sentences, with a metaphorical meaning. Cecilia, after drawing the human 'foot', writes the word 'pé' and interacts with Luíza in Libras, constructing the meaning of the expression, as can be seen in the following excerpt:

\section{Excerpt 1}

Cecilia: What is the sign (pointing to the drawing of a 'foot')?

Luíza: "Pé" (uses the sign for 'human foot' in Libras).

Cecília: I I used the letter 'L' here, but it can be any letter. I wanted to show here (pointing to the letter ' $L$ ' with legs) the meaning of 'letter'. If we do it in Libras as we do in Portuguese, it makes no sense, right? (signs 'human foot' and then 'letter'). We can't understand anything. Hearing people say it like this (pointing to the idiomatic expression 'ao pé da letra' written in blue on the board), when they want to mean 'literally'.

Luíza: Got it... but why do they say 'ao pé da letra'? (signs 'human foot' and 'letter'). Why do they say so? 
- Learning libras and portuguese in a tandem context: a study conducted with one deaf and one hearing student

Cecília: Do you remember when I explained here (pointing, on the whiteboard, to the drawing of the letter ' $\mathrm{L}$ ' with legs) that idiomatic expressions have no separate meaning, that they are metaphors?

Luíza I do, I remember. But I got curious.

Cecília: I confess I don't know why we say that way. I can only tell you that, when you want to say that someone does something literally, you say they do it 'ao pé da letra'.

As can be seen in this excerpt, when writing the letter ' $L$ ' on the whiteboard and assigning to it the image of a drawn human foot, Cecília provided an inadequate visual input to Luíza, since the drawing depicts the literal sense of the parts of the idiomatic expression, which caused some difficulty in understanding for her deaf partner. That difficulty was made worse because Cecilia was using Libras with the structure of Portuguese, which can occur when two languages of different modalities are being used simultaneously (EMMOREY et al., 2008). Such confusion could only be minimized when the students discussed the expression, with Cecília having clarified, to her deaf partner, that idiomatic expressions have a metaphorical meaning, and not a literal meaning, as Faria argues (2003).

In this example, we can perceive the different mediating strategies that Cecilia used (the writing in blue - to show the correct spelling of the idiomatic expression - and the drawing of the letter ' $\mathrm{L}$ ' with 'human feet') to explain the meaning of the idiomatic expression to her deaf partner. Even though the strategy was relevant - since, at first, Cecília managed to make sense of the Portuguese spellings for 'letter' and 'foot' - the fact that she translated an idiomatic expression in parts made its comprehension harder, since it drew the deaf partner's attention to the literal meaning of these parts and not to the metaphorical meaning of the expression, as Faria (2003) and Oliveira (2010) warn us.

In excerpt 2, Cecília gives Luíza a handout and asks her to match the idiomatic expressions to some images. After doing the matching task, Luíza had to write some sentences using the expressions. In the interaction below, the participants are talking about the expression 'falar pelos cotovelos' 10 .

10 Literally, the expression is translated as 'talk through/out of the elbows'. The expression 'falar pelos cotovelos' is used to refer to someone who talks too much, too quickly, similar to the English expression 'talk nineteen to the dozen'. 
- Learning libras and portuguese in a tandem context: a study conducted with one deaf and one hearing student

\section{Excerpt 2}

Cecilia Here (pointing to the second part of the activity, where there are only lines), I want you to think of an example using the expression (points to the part in the activity in which Luíza wrote 'falar pelos cotovelos'.)

Luíza Ok, let me think... (after a few seconds, she begins to write on the board: 'Cecília falar cotovelos aula Libras'il) (laughing).

Cecília You are being so mean... (starts laughing too) Ok, the expression is perfect, but here (pointing to the verb 'falar' in the sentence), it's not Cecilia falar. You know how we conjugate verbs in Portuguese, right? How does it go?

Luíza F-A-L-O (using fingerspelling ${ }^{12}$ ).

Cecília F-A-L-O (using fingerspelling), can only be used in Portuguese with the pronoun ' $\mathrm{E}-\mathrm{U}$ ' (I, in English) (using fingerspelling). Cecília goes with which pronoun?

Luíza E-L-A (She, in English) (using fingerspelling)?

Cecília Exactly. She. How do we conjugate the verb 'falar with the pronoun 'ela'?

Luíza F-A-L-A? (using fingerspelling)

Cecília Exactly! Ela F-A-L-A (She talks, in English) (using fingerspelling).

This example illustrates a process of co-construction of knowledge favored by collaborative learning (FIGUEIREDO, 2006; SWAIN, 1995). The moment Cecília takes Luíza to reflect on how verbs in Portuguese are conjugated, she provides her deaf partner with scaffoldings (WOOD; BRUNER; ROSS, 1976) by directing questions at her. Cecília invites Luíza to think about the grammatical structures of Portuguese, offering hints and facial expressions as scaffoldings to help Luíza produce the verbal conjugation of the verb 'falar' in the third person singular and, thus, reaches the correct final answer in Portuguese (ela fala).

In the following excerpt, we illustrate an interaction in which Luíza teaches the idiomatic expression 'cara de pau'13 in Libras. In order to do so, she uses a video in which a man is walking with his wife, and another woman, who is very beautiful and attractive, passes by them. The husband, then, looks at the woman, and the wife realizes what is happening and slaps his face.

11 In this example, Luiza uses the verb 'falar' in the infinitive form. She does not conjugate the verb.

12 Fingerspelling (or dactylology) is the act of representing the letters of a writing system, and sometimes numeral systems, using only the hands (QUADROS; KARNOPP, 2004; SANDLER; LILLO-MARTIN, 2006).

13 Literally, 'face of wood' or 'wood face'. The meaning is very close to 'shameless', in describing a person that has no regard for what others think of them. 
- Learning libras and portuguese in a tandem context: a study conducted with one deaf and one hearing student

After watching the video, Luiza tells her partner, in Libras: He is 'cara de pau', presenting the expression in Libras, as we can see in excerpt 3.

Excerpt 3

Luíza: Got it? He looked at the other woman from head to toe. He is 'cara de pau' (signs the equivalent idiomatic expression in Libras for 'cara de pau').

Cecilia: What sign is this? (repeats the sign for the corresponding idiomatic expression in Libras for 'cara de pau').

Luíza: It's like in Portuguese 'C-A-R-A-P-A-U' (using fingerspelling). A shameless person.

Cecília: No (gets up, takes the marker and goes to the whiteboard and writes 'cara de pau'). In Portuguese, we say "C-A-R-A-D-E-P-A-U" (using fingerspelling). It needs a 'D-E' (using fingerspelling). Got it?

Theoreticians of tandem learning (BENEDETTI, 2010; BRAMMERTS, 1996) advocate that there must be specific moments for the teaching of each language during the tandem sessions. However, excerpt 3 shows us that the languages are used when the students need them. This fact illustrates that the participants exert real autonomy over which language to use when they interact during the tandem sessions.

During the interview, when talking about their experiences in the face-to-face tandem sessions, the participants highlighted more positive aspects than negative ones. In the following excerpts we can see that they appreciated the opportunity of being able to learn from each other.

Excerpt 4

I thought it was very good because I learned a lot from her, much more naturally than in the Libras classroom. The fun thing is that, by interacting with the deaf, I have to find a way to communicate and, when doing that, I'm learning many more signs. Sometimes, we depart from the content of the class, but we continue learning new signs, and that's important too, right? By interacting with Luíza, I can learn more about the deaf culture, Libras grammar, and why we're not focusing only on the content.

[Interview - Cecília] 
Excerpt 5

I really enjoyed learning Portuguese from my partner, but I found it difficult because there were times when I couldn't understand what she was saying. Sometimes she signs using the Portuguese structure, and that's very hard for me to understand, but I liked the activities a lot, and she is very nice to me. She has a lot of patience when teaching Portuguese to me because she knows that we, deaf people, do not learn Portuguese as a second language in school, and because of that she explained the meaning of the words to me. I also enjoyed teaching her Libras, because I had to prepare the lessons, think about what I was going to teach, look for the video to show the expression in Libras. I felt motivated by this approach.

[Interview - Luíza]

The data used in this paper illustrate the relevance of collaboration in the interactions in the language classroom, as is stated by Donato and McCormick (1994), Swain (1995) and Figueiredo (2006). These authors emphasize that efficient learning takes place when students have the chance to interact and to learn from each other, which leads to a process of co-construction of knowledge.

\section{Final remarks}

We noticed that the interactions in tandem favored the learning of Portuguese and Libras, as the participants used several strategies that could mediate the learning process. Among the strategies used by them, we highlight the use of videos, drawings, writing on the whiteboard with different colors, fingerspelling, examples, tasks to be done, and facial expressions. The scaffoldings were provided through questions that led the participants to reflect on the content being studied.

We also highlight that there was alternation between the roles of the participants of this study when they taught their native language or learned the target language, thus making the learning process much more significant to them. In the interactions, we observed the principles of reciprocity and autonomy, with Libras being the language in the interaction, characterizing it as an anchorage language in this process of learning.

The analysis of the data allows us to state that the alternating roles, promoted during the tandem interactions between Cecília and Luíza, were fundamental in the learning process of the languages involved in the interaction between them. The participants of this study had the chance to have a very active role in that process, acting as teacher and 
- Learning libras and portuguese in a tandem context: a study conducted with one deaf and one hearing student

learner. That fact is of extreme relevance if we consider that the participants are studying to be language teachers. The data also allow us to state that tandem learning is a very useful collaborative approach to be used in contexts where two languages of different modalities are being used, as is the case of Portuguese and Libras.

The examples illustrated in this paper allow us to say that if we seek for true learning in our classes, we should provide learners with opportunities for interaction and collaboration by which they can become responsible for their own learning, so that they can develop autonomy by co-constructing knowledge and by being active in this process.

\section{References}

BENEDETTI, A. M. Dos princípios de tandem ao teletandem. In: BENEDETTI, A. M.; CONSOLO, D. A.; VIEIRA-ABRAHÃO, M. H. (org.). Pesquisas em ensino e aprendizagem no teletandem Brasil: línguas estrangeiras para todos. Campinas: Pontes, 2010. p. 21-45.

BIDERMAN, M. T. C. Teoria lingüística: teoria lexical e lingüística computacional. 2. ed. São Paulo: Martins Fontes, 2001.

BOGDAN, R.; BIKLEN, S. Investigação qualitativa em educação: uma introdução à teoria e aos métodos. Porto: Porto Editora, 1994.

BRAMMERTS, $\mathrm{H}$. Tandem language learning via the internet and the International E-Mail Tandem Network. In: LITTLE, D.; BRAMMERTS, H. (Ed.). A guide to language learning in tandem via the Internet. CLCS Occasional Paper, n. 46, Dublin: Trinity College, Centre for Language and Communication Studies, 1996. p. 9-22. Disponível em: http://files.eric. ed.gov/fulltext/ED399789.pdf. Acesso em: 7 maio 2017.

BRAMMERTS, H. Aprendizagem autônoma de línguas em tandem: desenvolvimento de um conceito. In: DELILLE, K. H.; CHICHORRO, A. (org.). Aprendizagem autônoma de línguas em tandem. Lisboa: Colibri, 2002. p. 15-25.

DONATO, R.; MCCORMICK, D. A sociocultural perspective on language learning strategies: The role of mediation. The Modern Language Journal, v. 78, n. 4, p. 453-464, 1994.

EMMOREY, K.; BORINSTEIN, H.; THOMPSON, R.; GOLLAN, T. Bimodal bilingualism. Bilingualism: Language and Cognition, v. 11, n. 1, p. 43-61, 2008. 
FARIA, S. P. A metáfora na LSB e a construção dos sentidos no desenvolvimento da competência comunicativa de alunos surdos. 2003. Dissertação (Mestrado em Linguística) - Instituto de Letras, Universidade de Brasília, Brasília, 2003.

FIGUEIREDO, F. J. Q. de. Understanding the interaction that occurs during peer correction activities and its effects on the revision of written texts. Signótica - Revista do Mestrado em Letras e Linguística, Goiânia, v. 11, p. 51-74, 1999.

FIGUEIREDO, F. J. Q. de. Correção com os pares: os efeitos do processo da correção dialogada na aprendizagem da escrita em língua inglesa. 2001. Tese (Doutorado em Letras: Estudos Linguísticos) - Faculdade de Letras, Universidade Federal de Minas Gerais, Belo Horizonte, 2001.

FIGUEIREDO, F. J. Q. de. Semeando a interação: a revisão dialógica de textos escritos em língua estrangeira. Goiânia: Ed. UFG, 2005.

FIGUEIREDO, F. J. Q. de. A aprendizagem colaborativa de línguas: algumas considerações conceituais e terminológicas. In: FIGUEIREDO, F. J. Q. de. (Org.). A aprendizagem colaborativa de línguas. Goiânia: Ed. UFG, 2006. p. 11-45.

FIGUEIREDO, F. J. Q. de. Aprendendo com os erros: uma perspectiva comunicativa de ensino de línguas. 3. ed. rev. ampl. Goiânia: Editora UFG, 2015.

FIGUEIREDO, F. J. Q. de.; SILVA, S. V. Do tandem ao teletandem: estudos sobre o uso da colaboração na aprendizagem de línguas em contexto virtual. In: JORDÃO, C. M. (Org.). A linguística aplicada no Brasil: rumos e passagens. Campinas: Pontes, 2016. p. 309-335.

GARCIA, D. N. M. O que os pares de Teletandem (não) negociam: práticas para um novo contexto online interativo para o ensino/aprendizagem de línguas estrangeiras no século XXI. São Paulo: Editora UNESP, 2013.

LANTOLF, J.; APPEL, G. Theoretical framework: an introduction to vygotskian perspectives on second language research. In: LANTOLF, J.; APPEL, G. (Ed.). Vygotskian approaches to second language research. New Jersey: Ablex Publishing Corporation, 1994. p. 1-32.

NUNAN, D. Research methods in language learning. New York: Cambridge University Press, 1992. 
- Learning libras and portuguese in a tandem context: a study conducted with one deaf and one hearing student

OLIVEIRA, D. F. A. Professor, tem alguém ficando para trás! As crenças de professores influenciando a cultura de ensino/aprendizagem de LE de alunos surdos. 2007. Dissertação (Mestrado em Linguística Aplicada) - Universidade de Brasília, Brasília, 2007.

OLIVEIRA, P. H. Metáfora conceptual e língua brasileira de sinais - libras. In: CONGRESSO NACIONAL DE LINGUÍSTICA E FILOLOGIA, 14., 2010, Rio de Janeiro. Anais... Rio de Janeiro: Instituto de Letras, Universidade do Estado do Rio de Janeiro, 2010. p. 2836-2851.

OLIVEIRA-SILVA, C. M. O surdo na escola inclusiva aprendendo uma língua estrangeira (inglês): um desafio para professores e alunos. 2005. Dissertação (Mestrado em Linguística Aplicada) - Universidade de Brasília, Brasília, 2005.

OLIVEIRA-SILVA, C. M. A aprendizagem colaborativa de inglês instrumental por alunos surdos: um estudo com alunos do curso de Letras: Libras da UFG. 2017. Tese (Doutorado em Letras e Linguística) - Faculdade de Letras, Universidade Federal de Goiás, Goiânia, 2017.

QUADROS, R. M.; KARNOPP, L. B. Língua de sinais brasileira: estudos linguísticos. Porto Alegre: Artmed, 2004.

SANDLER, W.; LILLO-MARTIN, D. Sign language and linguistic universals. Cambridge: Cambridge University Press, 2006.

SELIGER, H. W.; SHOHAMY, E. Second language research methods. Oxford: Oxford University Press, 1989.

SOUZA, R. A. Telecolaboração e divergência em uma experiência de aprendizagem de português e inglês como línguas estrangeiras. Revista Brasileira de Linguística Aplicada, v. 3, n. 2, p. 73-96, 2003.

SOUZA, R. A. Telecolaboração na aprendizagem de línguas estrangeiras: um estudo sobre o regime de tandem. In: FIGUEIREDO, F. J. Q. de. (Org.). A aprendizagem colaborativa de línguas. Goiânia: Editora da UFG, 2006. p. 255-276.

SWAIN, M. Three functions of output in second language learning. In: COOK, G.; SEIDLHOFER, B. (Ed.). Principle \& practice in applied linguistics. Oxford: Oxford University Press, 1995, p. 125-144. 
TELLES, J. A. Telet@andem: Um contexto virtual, autônomo e colaborativo para aprendizagem de línguas estrangeiras no século XXI. Campinas: Pontes Editores, 2009.

VASSALLO, M. L.; TELLES, J. A. Ensino e Aprendizagem de línguas em tandem: princípios teóricos e perspectivas de pesquisa. In: TELLES, J. A. (Org.). Telet@andem: um contexto virtual, autônomo e colaborativo para aprendizagem de línguas estrangeiras no século XXI. Campinas: Pontes, 2009. p. 21-42.

VILLAMIL, O. S.; GUERRERO, M. C. M. Peer revision in the L2 classroom: social-cognitive activities, mediating strategies, and aspects of social behavior. Journal of Second Language Writing, v. 5, n. 1, p. 51-75, 1996.

WOOD, D.; BRUNER, J. S.; ROSS, G. The role of tutoring in problem solving. Journal of Child Psychology and Psychiatry, v. 17, p. 89-100, 1976.

COMO CITAR ESTE ARTIGO: FIGUEIREDO, Francisco José Quaresma de; OLIVEIRA, Quintino Martins de. A deaf and a hearing student learning Portuguese and Libras in a tandem context. Revista do GEL, v. 15, n. 3, p. 58-72, 2018. Disponível em: https://revistadogel.gel.org.br/

DOI: http://dx.doi.org/10.21165/gel.v15i3.2389

Submetido em: 24/10/2018 | Aceito em: 12/12/2018. 